\title{
KAROLINA STOPKA
}

ORCID: 0000-0003-1199-9350

Uniwersytet Wrocławski

\section{RYZYKO SZKODY POWSTAŁEJ W SZCZEGÓLNYCH OKOLICZNOŚCIACH*}

\begin{abstract}
Abstrakt: Ryzyko socjalne jest kategorią teoretycznoprawną powszechnie stosowaną w rozważaniach na temat instytucji prawnych zabezpieczenia społecznego, w tym służącą do opisu funkcji świadczeń zabezpieczenia społecznego oraz wyróżnienia i charakteryzacji prawa zabezpieczenia społecznego (prawa socjalnego). W opracowaniu autorka wskazuje na normatywne podstawy wyodrębnia ryzyka szkody powstałej w szczególnych okolicznościach oraz dokonuje jego teoretycznoprawnej analizy. Wyjaśnia kwestie terminologiczne oraz opisuje konstrukcję tego ryzyka, jego treść oraz aktualny i postulowany zakres jego ochrony.
\end{abstract}

Słowa kluczowe: ryzyko socjalne, prawo socjalne, szkoda na osobie, odszkodowanie socjalne, świadczenia zaopatrzeniowe

\section{UWAGI WPROWADZAJĄCE}

Ryzyko szkody powstałej w szczególnych okolicznościach jest kategorią teoretycznoprawną przydatną do charakteryzowania odszkodowania socjalnego jako formy prawnej realizacji zabezpieczenia społecznego. Ryzyko to jest ryzykiem jednostki funkcjonującej w danej społeczności, która angażuje się w działania prospołeczne niestanowiące źródła jej utrzymania, działa, podporządkowując się woli państwa, które w interesie ogólnym zobowiązuje ją do określonych zachowań (postaw), lub która ponosi konsekwencje nieudolności państwa w realizacji jego zadań. Tak rozumiane ryzyko przynależy do sfery społecznego, a nie rodzinnego czy też zawodowego życia codziennego jednostki.

W sensie rodzajowym ryzyko szkody powstałej w szczególnych okolicznościach nie należy do tak zwanych klasycznych, modelowych ryzyk socjalnych. Nie korzysta również z przymiotu oczywistości. Ryzyko to nie występuje po-

* Opracowanie oparte na wnioskach wynikających z rozważań zawartych w monografii własnej — K. Stopka, Świadczenia odszkodowania socjalnego w prawie polskim, Warszawa 2018, s. 307 - i wykorzystanym tam piśmiennictwie. 
wszechnie w polskim języku prawniczym. Termin ten nie należy bowiem do języka prawnego. Nie posługuje się nim ustawodawstwo krajowe. Nie ma również bezpośrednich podstaw do jego wyodrębnienia w aktach prawnomiędzynarodowych wyznaczających współcześnie zakres zabezpieczenia społecznego. Zwłaszcza konwencja MOP nr 102 nie normuje świadczeń, które byłyby podstawą do jego wyodrębnienia. Wprost wskazują na takie świadczenia jedynie akty normujące koordynację krajowych systemów zabezpieczenia społecznego, mimo iż nie obejmują ich jej mechanizmem ${ }^{1}$, oraz dyrektywa Rady nr 2004/80/WE z 29 kwietnia 2004 roku odnosząca się do kompensaty dla ofiar przestępstw, która zobowiązała państwa członkowskie UE do wprowadzenia systemu gwarantującego sprawiedliwą i odpowiednią kompensatę ofiarom umyślnych przestępstw z użyciem przemocy, popełnionych na ich terytoriach ${ }^{2}$.

Choć jak już wskazano, termin ,ryzyko szkody losowej powstałej w szczególnych okolicznościach" nie jest zwrotem normatywnym, polskie ustawodawstwo daje podstawy do jego doktrynalnego wyodrębnienia. Za przejaw ochrony tego ryzyka uznać należy przede wszystkim świadczenia kompensujące następstwa śmierci lub naruszenia dobrostanu fizycznego, psychicznego lub społecznego jednostki, zaistniałe w wyniku popełnienia czynu zabronionego lub związane z wydarzeniami historycznymi (II wojną światową, okresem powojennym, walką o demokratyzację stosunków społecznych), a także z prospołeczną aktywnością życiową jednostki w wymiarze lokalnym oraz globalnym. Świadczenia te unormowane są w przepisach: ustawy z 7 maja 2005 roku o państwowej kompensacie przysługującej ofiarom niektórych czynów zabronionych ${ }^{3}$; ustawy z 29 maja 1974

1 Tak np. Europejska konwencja o zabezpieczeniu społecznym z 14 grudnia 1972 roku w odniesieniu do świadczeń na rzecz ofiar wojny lub jej następstw (art. 2 ust. 4); rozporządzenie nr 883/2004 Parlamentu Europejskiego i Rady z dnia 29 kwietnia 2004 roku w sprawie koordynacji systemów zabezpieczenia społecznego (Dz. Urz. UE L 166 z 30.04.2004 r., s. 1) w odniesieniu do świadczeń, w związku z którymi państwo członkowskie przejmuje odpowiedzialność za szkody wyrządzone osobom i zapewnia odszkodowanie, takich jak świadczenia dla ofiar wojny i działań wojennych lub ich skutków, ofiar zbrodni, zabójstw lub aktów terroryzmu, ofiar szkód spowodowanych przez funkcjonariuszy państwa członkowskiego podczas wykonywania ich obowiązków lub dla osób, które znalazły się w niekorzystnej sytuacji ze względów politycznych lub religijnych lub też ze względu na pochodzenie (art. 3 ust. 5); wcześniej obowiązujące rozporządzenie nr 14807/71 z 14 czerwca 1971 roku w sprawie stosowania systemów zabezpieczenia społecznego do pracowników najemnych i ich rodzin przemieszczających się we Wspólnocie (Dz. Urz. UE L 1971, Nr 149, s. 2 ze zm.) w stosunku do systemów świadczeń dla ofiar wojny lub jej skutków (art. 4 ust. 4) oraz przepisy obowiązujące w ramach EWG (rozporządzenie nr 3 z 25 września 1958 roku dotyczące ubezpieczenia społecznego pracowników migrujących, Dz. Urz. WE P 30 z 16.12.1958 r., s. 597-664). Krytycznie na temat wyłączenia świadczeń odszkodowania socjalnego spod działania rozporządzenia nr 1408/71 pisze E. Eichenhofer we wstępie do pracy zbiorowej Reform des Europäischen koordinierenden Sozialrechts - cyt. za: H. Szurgacz, Europejska Konwencja o zabezpieczeniu społecznym, [w:] Europejskie prawo pracy i ubezpieczeń społecznych, red. L. Florek, Warszawa 1996, s. 291.

2 Dz.U. L 261 z 6.08 .2004 r., s. 15-18 ze zm.

3 Tekst jedn. Dz.U. z 2016 r. poz. 325; dalej: ustawa o kompensacie. 
roku o zaopatrzeniu inwalidów wojennych i wojskowych oraz ich rodzin ${ }^{4}$; ustawy z 24 stycznia 1991 roku o kombatantach oraz niektórych osobach będących ofiarami represji wojennych i okresu powojennego $0^{5}$; ustawy z 2 września 1994 roku o świadczeniu pieniężnym i uprawnieniach przysługujących żołnierzom zastępczej służby wojskowej przymusowo zatrudnianym w kopalniach węgla, kamieniołomach, zakładach rud uranu i batalionach budowlanych ${ }^{6}$; ustawy z 7 maja 2009 roku o zadośćuczynieniu rodzinom ofiar zbiorowych wystąpień wolnościowych w latach 1956-19897; ustawy z 31 maja 1996 roku o osobach deportowanych do pracy przymusowej oraz osadzonych w obozach pracy przez III Rzeszę i Związek Socjalistycznych Republik Radzieckich ${ }^{8}$; ustawy z 16 listopada 2006 roku o świadczeniu pieniężnym i uprawnieniach przysługujących cywilnym niewidomym ofiarom działań wojennych ${ }^{9}$; ustawy z 20 marca 2015 roku o działaczach opozycji antykomunistycznej oraz osobach represjonowanych z powodów politycznych ${ }^{10}$; ustawy z 19 sierpnia 2011 roku o weteranach działań poza granicami państwa ${ }^{11}$; ustawy z 30 października 2002 roku o zaopatrzeniu z tytułu wypadków lub chorób zawodowych powstałych w szczególnych okolicznościach ${ }^{12}$ oraz w aktach wykonawczych normujących świadczenia z tytułu szkód powstałych podczas lub $\mathrm{w}$ związku z udzielaniem pomocy służbom mundurowym ${ }^{13}$.

4 Tekst jedn. Dz.U. z 2020 r. poz. 203 ze zm.

5 Tekst jedn. Dz.U. z 2020 r. poz. 517; dalej: ustawa kombatancka.

6 Tekst jedn. Dz.U. z 2020 r. poz. 619.

7 Tekst jedn. Dz.U. z 2020 r. poz. 678; dalej: ustawa o zadośćuczynieniu.

8 Tekst jedn. Dz.U. z 2019 r. poz. 1168.

9 Tekst jedn. Dz.U. z 2020 r. poz. 684.

10 Tekst jedn. Dz.U. z 2020 r. poz. 319; dalej: ustawa o działaczach opozycji antykomunistycznej.

11 Tekst jedn. Dz.U. z 2019 r. poz. 1569 ze zm.; dalej ustawa o weteranach.

12 Tekst jedn. Dz.U. z 2020 r. poz. 984.

13 Rozporządzenie Ministra Spraw Wewnętrznych z 15 października 1991 roku w sprawie zasad i trybu przyznawania świadczeń odszkodowawczych przysługujących w razie utraty życia lub poniesienia uszczerbku na zdrowiu albo szkody w mieniu podczas udzielania lub w związku z udzielaniem pomocy Policji, Urzędowi Ochrony Państwa lub Straży Granicznej (Dz.U. z 1991 r. Nr 98, poz. 437 ze zm.). Z dniem 2 stycznia 1998 roku rozporządzenie utraciło częściowo podstawę prawną na skutek zmiany ustawy z dnia 6 kwietnia 1990 roku o Urzędzie Ochrony Państwa przez art. 34 ustawy z dnia 8 sierpnia 1996 roku o zmianie niektórych ustaw normujących funkcjonowanie gospodarki i administracji publicznej (Dz.U. Nr 106, poz. 496) — zob. art. 75 wyżej wymienionej ustawy. $\mathrm{Z}$ dniem 25 września 1998 roku rozporządzenie utraciło moc w zakresie uregulowanym rozporządzeniem Ministra Spraw Wewnętrznych i Administracji z dnia 31 sierpnia 1998 roku w sprawie zasad i trybu przyznawania odszkodowań przysługujących w razie utraty życia albo poniesienia uszczerbku na zdrowiu lub szkody w mieniu podczas udzielania Straży Granicznej lub w związku z jej udzielaniem (Dz.U. Nr 118, poz. 767) na podstawie § 20 rozporządzenia). Zob. też rozporządzenie Ministra Spraw Wewnętrznych i Administracji z 31 sierpnia 1998 roku w sprawie zasad i trybu przyznawania odszkodowań przysługujących w razie utraty życia albo poniesienia uszczerbku na zdrowiu lub szkody na mieniu podczas udzielania pomocy Straży Granicznej lub w związku z jej udzielaniem (Dz.U. z 1998 r. Nr 118, poz. 767); rozporządzenie Ministra Spraw Wewnętrznych i Administracji z 26 listopada 1997 roku w sprawie zakresu, szczegółowych zasad i trybu przyznawania świadczeń 


\section{KWESTIE TERMINOLOGICZNE ORAZ KONSTRUKCJA RYZYKA SZKODY POWSTAŁEJ W SZCZEGÓLNYCH OKOLICZNOŚCIACH}

Nazwa analizowanego ryzyka ma charakter złożony i prima facie wydaje się mało precyzyjna. Jako taka jest jednak konsekwencją wielości i zróżnicowania regulacji ustawowych normujących świadczenia mogące uchodzić za przejaw ochrony tego ryzyka i niewielkiego stopnia zaawansowania badań naukowych nad nimi oraz koncepcją odszkodowania socjalnego w Polsce jako formy prawnej jego ochrony.

Przyjęta nazwa łączy oba spotykane w nauce sposoby nazywania ryzyka socjalnego. Wskazuje na przedmiot ochrony (szkoda) oraz uwarunkowania, w których powstaje szkoda rodząca potrzebę wymagającą zabezpieczenia, pozwalające z kolei dookreślić jego zakres podmiotowy.

Przedmiot ochrony w nazwie prezentowanego ryzyka ujęty jest w sposób bardzo ogólny (szkoda). Generalnie szkoda jest zjawiskiem czysto faktycznym, naturalnym, istniejącym niezależnie od prawa i prawnie niezdefiniowanym. W ujęciu omawianego ryzyka szkoda oznacza śmierć lub naruszenie dobrostanu fizycznego, psychicznego lub społecznego jednostki. Odnosi się zatem do dóbr osobistych jednostki, takich jak życie i zdrowie, oraz podkreśla różnorodność potrzeb, zaspokajanych lub łagodzonych w ramach świadczeń, które mają na celu ich kompensowanie.

Szczególne okoliczności doznania szkody dookreślają natomiast to ryzyko podwójnie. Są jednocześnie o tyle osobliwe, że mogą uchodzić za samodzielny tytuł ochrony, istotny dla podkreślenia wprost w nazwie ryzyka.

Po pierwsze, szczególne okoliczności eksponują, że ryzyko to odnosi się do szkód, których powstanie nie tkwi wyłącznie w sposobie funkcjonowania organizmu jednostki, lecz ma jakieś pozabiologiczne źródło czy też uwarunkowanie. Ryzyko to odnosi się więc do szkód powstałych ze względu na jakąś sytuację. Sytuacje te, oceniane pod kątem faktów, wydarzeń towarzyszących doznaniu szkody, pochodzenia zdarzenia szkodzącego czy zasięgu zagrożenia związanego z jego

\footnotetext{
i odszkodowań osobom niebędącym strażakami w razie wypadku lub poniesienia szkody w mieniu w związku z udzielaniem pomocy lub udziałem w ćwiczeniach organizowanych przez Państwową Straż Pożarną (Dz.U. z 1997 r. Nr 145, poz. 980 ze zm.); rozporządzenie Prezesa Rady Ministrów z 22 sierpnia 2003 roku w sprawie odszkodowań przyznawanych osobom udzielającym pomocy Agencji Bezpieczeństwa Wewnętrznego, niebędącym jej funkcjonariuszami (Dz.U. z 2003 r. Nr 160, poz. 1558); rozporządzenie Prezesa Rady Ministrów z 26 listopada 2003 roku w sprawie odszkodowań przyznawanych osobom udzielającym pomocy Agencji Wywiadu, niebędącym jej funkcjonariuszami (Dz.U. z 2003 r. Nr 208, poz. 2024). Na marginesie warto odnotować, że do 28 lutego 2017 roku tego rodzaju świadczenia regulowało również rozporządzenie Ministra Finansów z 15 kwietnia 2004 roku w sprawie sposobu i trybu ustalania wysokości i przyznawania odszkodowania osobom udzielającym pomocy pracownikom wywiadu skarbowego (Dz.U. z 2004 r. Nr 71, poz. 647). Rozporządzenie to utraciło moc obowiązującą z dniem 28 lutego 2017 roku w związku z uchyleniem jego podstawy prawnej przez ustawę z dnia 16 listopada 2016 roku. Por. też przepisy wprowadzające ustawę o Krajowej Administracji Skarbowej (Dz.U. z 2016 r. poz. 1948).
} 
działaniem, nie tworzą jednorodnej grupy, dającej się określić bardziej precyzyjną i skrótową nazwą. W ich przypadku należy mówić o kilku grupach, niekoniecznie związanych z wkładem jednostki (to jest wkładem niematerialnym dla dobra ogółu przybierającym różną postać - ofiarności, poświęcenia, zasługi lub tylko działalności użytecznościowej) ${ }^{14}$, w tym również w odniesieniu do świadczeń unormowanych w jednym akcie prawnym. Okoliczności te łączy natomiast ich społeczne uwarunkowanie, na przykład stanem rozwoju danego społeczeństwa, zawodnością jego organizacji, niedostatecznością lub nieskutecznością jego urządzeń, polityki, oraz związek z dobrami prawnie chronionymi o podstawowym znaczeniu dla państwa i społeczeństwa, to jest w świetle Konstytucji RP, w szczególności: walką o niepodległość, możliwością suwerennego i demokratycznego stanowienia o losie ojczyny, dobrem rodziny ludzkiej, nietykalnością osobistą, życiem pozostającym pod ochroną RP, oraz bezpieczeństwem obywateli, które zapewnia RP.

Ponadto dopełniający nazwę tego ryzyka zwrot „szczególne okoliczności” sygnalizuje, że ryzyko szkód powstałych w szczególnych okolicznościach nie ma związku z aktywnością zarobkową/zawodową jednostki ${ }^{15}$, która z perspektywy podstawowego wzorca zabezpieczenia społecznego, opartego na założeniu, że każdy dorosły człowiek ma możność i jest zobowiązany do zarabiania pracą najemną lub samodzielną na utrzymanie swoje i swojej rodzin ${ }^{16}$, jest typową sytuacją rodzącą ochronę socjalną. Uznanie pracy za podstawową rolę społeczną jednostki oraz podstawowe źródło zaspokajania jej potrzeb prowadzi do wniosku, że okoliczności doznania szkody niezwiązane z aktywnością zarobkową mają charakter nietypowy, niepowszechny i już w tym wyraża się ich szczególność. Ich ochrona stanowi jednocześnie wyraz tego, że zabezpieczenie społeczne, skonstruowane na podstawie wskazanej reguły społecznej, nie jest wystarczające do zapewnienia bezpieczeństwa socjalnego wszystkim jednostkom oraz że wartości społecznej życia jej członków nie należy postrzegać jedynie przez pryzmat ich aktywności zarobkowej ${ }^{17}$. Uwidoczniły to zwłaszcza wydarzenia I i II wojny światowej i okresu powojennego ${ }^{18}$. Uświadomiony wówczas solidaryzm narodowy zapoczątkował $\mathrm{w}$ Europie proces obejmowania ochroną $\mathrm{w}$ ramach zabezpieczenia społecznego

14 Przy podziale na okoliczności zależne i niezależne od wkładu jednostki nie chodzi o przyczynienie się jednostki (poszkodowanego) do zaistnienia zdarzenia szkodzącego czy też szkody, ile o jej postawę, rolę w obliczu jego zadziałania. Przykładowo wojna zagraża zarówno osobom czynnie w nią zaangażowanym, to jest wchodzącym w skład różnych formacji wojskowych oraz pokrewnych, jak i osobom pod tym względem biernym, określanym cywilnymi ofiarami wojny.

15 Szkoda nie jest uwarunkowana wykonywaniem tej aktywności lub nie powstała w okresie jej wykonywania.

16 Zob H.F. Zacher, Rozwój zabezpieczenia społecznego w Europie, [w:] Lad społeczny w Polsce i Niemczech na tle jednoczacej się Europy, red. M. von Bernd, T. Zieliński, Warszawa 1999, s. 373, 376; K. Ślebzak, Prawo do zabezpieczenia społecznego w Konstytucji RP. Zagadnienia podstawowe, Warszawa 2015, s. 84.

17 Szerzej K. Stopka, op. cit., s. 54-55 i przywołane tam piśmiennictwo.

18 Por. H.F. Zacher, op. cit., s. 379 n. Por. art. 2 lit. d. ustawy z 16 sierpnia 1923 roku o opiece społecznej (Dz.U. z 1923 r. Nr 92, poz., s. 726). 
szkód na osobie powstałych w okolicznościach pozazarobkowych, za które odpowiedzialność ponosi całe społeczeństwo. W piśmiennictwie przyjmuje się, że idea kompensowania tych szkód pierwotnie znalazła wyraz w formie świadczeń dla ofiar wojny, a w czasach pokoju również świadczeń dla ofiar zbrodni ${ }^{19}$.

Nazwa prezentowanego ryzyka — obejmująca skutek i przyczynę — sugeruje, że pod względem konstrukcyjnym ryzyko to ma charakter klasycznego ryzyka socjalnego, to jest ryzyka, które za J. Jończykiem na ogół rozumiane jest w nauce prawa zabezpieczenia społecznego (prawa socjalnego) jako niebezpieczeństwo wystąpienia zdarzenia przyszłego, niepewnego, niezależnego od woli człowieka i dlań niekorzystnego ${ }^{20}$. Konsekwentnie zaś świadczenia służące jego ochronie uznaje się za mające na celu ugruntowanie poczucia bezpieczeństwa socjalnego osób narażonych na zagrożenia ${ }^{21}$.

Przepisy wymienionych na wstępie ustaw nawiązują w swej treści do zdarzenia i przypisywanych mu cech poprzez: 1. powiązanie w regulacji prawnej świadczeń będących przejawem jego ochrony elementów wskazujących na przyczynę i skutek ${ }^{22}$ (na przykład doznanie określonych obrażeń na skutek czynu zabronionego, podczas korzystania lub w związku z korzystaniem przez Agencję Wywia$\mathrm{du}$ z pomocy poszkodowanych, przy wykonywaniu prac związanych ze spisami powszechnymi, przy wykonywaniu funkcji ławnika w sądzie); 2. używanie zwrotów odnoszących się wprost do tego terminu (uraz, zranienie, inne obrażenia, kontuzje, zranienia, eksplozja niewypałów i niewybuchów, działania wojenne); 3. konstrukcję chronionego wypadku (na przykład „wskutek wypadku pozostającego w związku działaniami poza granicami państwa”, wypadek w szczególnych okolicznościach), podkreślających kauzalny charakter tych świadczeń. Tylko świadczenia związane z wydarzeniami historycznymi (II wojną światową, okresem powojennym, walką o demokratyzację stosunków społecznych), nie służą ugruntowaniu poczucia bezpieczeństwa socjalnego we wskazanym rozumieniu. Świadczenia te nie mają bowiem charakteru prospektywnego, łagodzą skutki zdarzeń, które wystąpiły wiele lat przed wprowadzeniem ich do systemu prawnego. Odnoszenie pojęcia ryzyka socjalnego szkody powstałej w szczególnych okolicznościach również do szkód związanych z wydarzeniami historycznymi ma jednak swoje uzasadnienie.

Po pierwsze, ryzyko socjalne jest kategorią prawniczą. Po drugie, adresaci świadczeń uwarunkowanych zdarzeniami historycznymi w rezultacie zaistniałej przed laty sytuacji społeczno-politycznej w państwie i na świecie stanęli w obliczu ryzyka — niebezpieczeństwa doznania szkody. Po trzecie, z perspektywy polityki społecznej systemy ukształtowane „na wypadek” stanowią instrument prawny zarządzania zdefiniowanym ryzykiem, czyli rozpoznanym i zinterpretowanym

19 Por. H.F. Zacher, op. cit., s. 379, 386.

20 J. Jończyk, Prawo zabezpieczenia społecznego, Kraków 2006, s. 12.

21 Ibidem, s. 13.

22 Por. K. Roszewska, Ryzyko niezdolności do pracy, Warszawa 2018, s. 40. 
przyszłym możliwym stanem rzeczy, jakimś problemem społecznym ${ }^{23}$. W tym kontekście ustawodawstwo dotyczące zdarzeń historycznych nieukształtowane w pełni według formuły „na wypadek” można uznać albo za wyraz braku świadomości istnienia ryzyka, który wyklucza możliwość uruchomienia wobec niego stosownego postępowania antycypacyjnego ${ }^{24}$ (co w kontekście rozpatrywanych zdarzeń historycznych może dotyczyć czasu ,pokoju” — potencjalne, teoretyczne niebezpieczeństwo doznania szkody na osobie), albo braku podjętej w odpowiednim momencie reakcji ustawodawcy na ryzyko będące elementem rzeczywistości, czyli niebezpieczeństwo będące już w fazie realizacji (realne niebezpieczeństwo doznania szkody na osobie). Braki te można przy tym uznać za mniej lub bardziej usprawiedliwione, podyktowane: trudnością prawnego ujęcia ryzyka — jego nazwania, opisu i określenia właściwego mu rozwiązania instytucjonalnego, stopniem cywilizacyjnego zaawansowania danego społeczeństwa, aktualną sytuacją społeczną, gospodarczą oraz tak jak w przypadku kombatantów czy ofiar represji — względami polityczno-ustrojowymi — oceną determinowaną głoszonymi oficjalnie wartościami ${ }^{25}$. Nadto dla rozwoju systemu zabezpieczenia społecznego znamienne jest dostosowywanie jego form, w tym świadczeń, do aktualnych problemów społecznych — nowych niebezpieczeństw (ryzyk), które zaistniały, lub niebezpieczeństw wcześniej występujących, ale na przykład w mniejszym natężeniu i z tego lub innych względów (na przykład finansowych) nieujętych ramami prawnymi. O tym, czy ich ochrona przybierze formułe „na wypadek”, decyduje zatem tylko to, czy zaistniałe już w wymiarze społecznym niebezpieczeństwo może oddziaływać również w wymiarze jednostkowym na przyszłość — na osoby jeszcze nim niedotknięte. Stąd określenie, że dane świadczenia łączą się z niebezpieczeństwem, które się zmaterializowało i nie może oddziaływać na przyszłość - na przyszłość w wymiarze indywidualnym mogą oddziaływać tylko już jego następstwa, nie wydaje się wystarczające do wyłączenia możliwości posługiwania się wobec nich kategorią ryzyka socjalnego ${ }^{26}$.

23 Por. T. Szumlicz, Ubezpieczenie budynków od skutków ryzyk katastroficznych — aspekt społeczny rozwiązań wariantywnych, [w:] Ubezpieczenie budynków od ryzyk katastroficznych. Aspekty prawno-ekonomiczne, red. E. Kowalewski, Toruń 2013, s. 149, 151.

24 Por. T. Szumlicz, Świadomość ryzyka społecznego jako podstawa wiedzy o systemie ubezpieczeń społecznych, „Ubezpieczenia Społeczne. Teoria i praktyka” 2017, nr 1, s. 7.

25 Jak zaznacza H. Szurgacz, objęcie szerszą ochroną osób, które doznały szkód na osobie na skutek zdarzeń zaszłych, wyzwoliła dopiero demokratyzacja stosunków społecznych oraz przywrócenie godności ludzkiej należnej jej rang — idem, Prawo socjalne w latach 1989-1999. Kilka uwag o kierunkach rozwoju, [w:] Prawo pracy a wyzwania XXI w. Księga Jubileuszowa Profesora Tadeusza Zielińskiego, red. M. Matey-Tyrowicz, L. Lawacki, B. Wagner, Warszawa 2002, s. 528.

${ }^{26}$ Przeciwny pogląd prezentuje J. Jończyk. Jego zdaniem „kombatanctwo nie jest ryzykiem, nie jest zwłaszcza zdarzeniem przyszłym, a więc nie może tez być ryzykiem socjalnym. Nie istnieje zabezpieczenie na wypadek kombatanctwa. Świadczenia dla kombatantów są instytucją prawa administracyjnego, podobną do instytucji orderów i odznaczeń” — idem, op. cit., s. 21-22. 


\section{TREŚĆ RYZYKA SZKODY POWSTAŁEJ W SZCZEGÓLNYCH OKOLICZNOŚCIACH}

Istotą ryzyka szkody powstałej w szczególnych okolicznościach jest doznanie przez jednostkę szkody na osobie (życiu lub zdrowiu) w ustawowo określonych okolicznościach - bardziej lub mniej szczegółowo ujętych stanach faktycznych, niezwiązanych z aktywnością zarobkową jednostki, lecz ze społecznie pożądanymi postawami lub społecznie uwarunkowanymi zagrożeniami - mającymi za przedmiot lub związanymi z dobrami prawnie chronionymi o podstawowym znaczeniu dla państwa i społeczeństwa.

Szkoda musi się przynajmniej ujawnić w tych okolicznościach lub być następstwem konkretnych czynników towarzyszących danemu rodzajowi szczególnych okoliczności. Tak doznana szkoda jest, co do zasady, wprost wyrażona w tekście prawnym albo w przepisach określających świadczeniobiorcę, na przykład definicja inwalidy wojennego, inwalidy wojskowego, cywilnej niewidomej ofiary wojny, osoby uprawnionej do państwowej kompensaty, weterana poszkodowanego, albo opisane są warunki nabycia prawa do danego świadczenia każdorazowo przez wskazanie konkretnej postaci (dalej: tak zwana szkoda wyraźna), z reguły uszczerbek na zdrowiu o określonym stopniu, na przykład trwały, długotrwały lub ciężki, lub niezdolność do pracy (inwalidztwo), wyjątkowo jednocześnie uszczerbek na zdrowiu i niezdolność do pracy. Tylko w grupie niektórych świadczeń dotyczących zdarzeń historycznych szkoda nie jest wyrażona wprost, lecz jest zakodowana w okolicznościach historyczno-biograficznych stanowiących tytuł uprawnienia do świadczeń (praca przymusowa, przymusowe zatrudnienie, deportacja, działalność antykomunistyczna ${ }^{27}$ ). Okoliczności te ze swej natury wypada uznać za prowadzące do uszczerbku na zdrowiu z uwagi na generowany przez nie ból fizyczny i psychiczny. Świadczenia nieuwarunkowane konkretną postacią szkody na osobie są wyrazem dostrzeżenia przez ustawodawcę, już na etapie tworzenia prawa, trudności w oszacowaniu szkody i ujęciu jej w generalne formuły prawne, a w przypadku ujęcia jej w te formuły - trudności w jej wykazaniu. Przy takim założeniu, nawiązującym do koncepcji racjonalnego prawodawcy, który podejmuje decyzje prawodawcze na podstawie wiedzy i ocen, pominięcie szkody na osobie w hipotezie norm statuujących prawo do świadczeń należy traktować jako swoisty środek zapewnienia adekwatności tworzonych przepisów do zamierzeń prawodawcy w zakresie kompensacji szkód na osobie, mających źródło w odległych pod względem czasowym zdarzeniach, objętych ochroną prawną po wielu latach od momentu ich zaistnienia. Stosowanie tego środka zapobiega wprowadzaniu rozwiązań pozornych i fasadowych, w praktyce nieprowadzących do realizacji zakładanych celów. Taki stan należy uznać za właściwy, choć nie można oczywiście wykluczyć, że pominięcie w przepisach normujących prawo do

27 Zob. art. 2 i 3 ustawy o działaczach opozycji antykomunistycznej. 
świadczeń konkretnej postaci szkody stwarza tylko pozory podjęcia przez ustawodawcę merytorycznej decyzji w kwestii kompensacji szkód związanych z danymi okolicznościami historyczno-biograficznymi.

Tak ujęta szkoda - wyraźna i dorozumiana — jest z reguły jedyną, ewentualnie podstawową przesłanką warunkującą przyznanie prawa do świadczeń stanowiących, w ujęciu poszczególnych ustaw, podstawową formę jej kompensacji. Nawet jeśli przyznanie jakiegoś świadczenia wymaga spełnienia dodatkowych przesłanek (na przykład pobierania emerytury lub renty, osiągnięcia określonego wieku, zwolnienia ze służby), to przesłanki te nie są tak osobliwe, aby wpływały na ocenę tego, jakie ryzyko świadczenia chronią. Ich obecność tłumaczy albo forma świadczenia (na przykład dodatek, świadczenie wyrównawcze), albo wielość świadczeń adresowanych do danej grupy osób uprawnionych, wśród których podstawowy charakter ma renta $\mathrm{z}$ tytułu niezdolności do pracy i w stosunku do których Konstytucja wymaga wprowadzenia szczególnej ochrony ${ }^{28}$.

Poza tym rozmiar szkody, dla którego miarą w przypadku tak zwanej szkody wyraźnej jest procentowy stopień uszczerbku na zdrowiu lub stopień utraconej zdolności do pracy, ewentualnie utrata zdolności do samodzielnej egzystencji, a w przypadku tak zwanej szkody dorozumianej okres przymusowego zatrudnienia, pracy przymusowej lub deportacji, jest zarazem jedynym elementem wpływającym bezpośrednio na rozmiar świadczeń.

\section{ZAKRES OCHRONY RYZYKA SZKODY POWSTAŁEJ W SZCZEGÓLNYCH OKOLICZNOŚCIACH}

O zakresie ochrony ryzyka szkód powstałych w szczególnych okolicznościach można mówić w dwóch aspektach. Po pierwsze, w kontekście rodzaju kompensowanych skutków — przejawów — szkody i po drugie, w kontekście zasad ich kompensacji, w tym ich poziomu — wysokości świadczeń.

Ryzyko szkody losowej powstałej w szczególnych okolicznościach jest specyficzne i w sposób specyficzny chronione. Świadczenia chroniące to ryzyko adresowane są do bezpośrednio poszkodowanych oraz, w większości przypadków, do członków rodzin zmarłych poszkodowanych ${ }^{29}$. Zapewniają im jednak różny zakres i poziom ochrony socjalnej, który przy szczegółowej analizie świadczeń

28 Szerzej K. Stopka, op. cit., s. 180-183.

29 Świadczeń dla członków rodzin bezpośrednio poszkodowanych nie przewidują: ustawa o świadczeniu pieniężnym i uprawnieniach przysługujących żołnierzom zastępczej służby wojskowej przymusowo zatrudnianym w kopalniach węgla, kamieniołomach, zakładach rud uranu i batalionach budowlanych; ustawa o świadczeniu pieniężnym przysługującym osobom deportowanym do pracy przymusowej oraz osadzonym w obozach pracy przez III Rzeszę i Związek Socjalistycznych Republik Radzieckich; ustawa o świadczeniu pieniężnym i uprawnieniach przysługujących cywilnym niewidomym ofiarom działań wojennych oraz ustawa o weteranach działań poza granicami państwa. 
odnoszących się do poszczególnych typów okoliczności doznania szkody wskazuje, że ochrona ryzyka szkód powstałych w szczególnych okolicznościach nie jest ukształtowana na podstawie przemyślanej, spójnej koncepcji kompensacji szkód powstałych w szczególnych okolicznościach. Znamienne jednak dla regulacji prawnej tych świadczeń jest to, że są one zdeterminowane kontekstem doznania szkody i jej społeczną wartością, ocenianą przez pryzmat okoliczności jej doznania.

Generalnie z perspektywy aktualnie obowiązującej regulacji ryzyko szkody powstałej w szczególnych okolicznościach chronione jest najszerzej, gdy doznanie szkody związane jest z ofiarnością, poświęceniem, zasługami lub przynajmniej działalnością użytecznościową jednostki dla dobra ogółu. Zdecydowanie węższy zakres ochrony dotyczy szkód powstałych w okolicznościach społecznie uwarunkowanych, ale niezwiązanych z konkretnymi prospołecznymi postawami poszkodowanego. Znamienne dla kompensacji szkód doznanych w okolicznościach mogących uchodzić za przejaw ofiarności, poświęcenia czy zasług jednostki dla dobra ogółu jest przy tym występowanie oprócz świadczeń pieniężnych nastawionych na kompensację majątkowych następstw szkody na osobie, zwłaszcza w zakresie, w jakim wpływa ona na zdolność zarobkową jednostki, świadczeń w naturze oraz licznych szczególnych uprawnień i przywilejów, mogących uchodzić za przejaw kompensacji niemajątkowych następstw szkody na osobie w ramach zabezpieczenia społecznego (tak zwanego świadczenia socjalnego zabezpieczenia społecznego). Świadczenia te służą bowiem usprawnieniu funkcjonowania organizmu jednostki zakłóconego wskutek doznanych szkód, korzystniej kształtują jej sytuację prawną $\mathrm{w}$ określonych dziedzinach życia w porównaniu z pozostałymi członkami społeczeństwa przez przyznanie jej wyjątkowych uprawnień lub zwolnienie z określonych powinności czy też zapewnienie dodatkowego wsparcia w sytuacjach kryzysowych. Na możliwość programowego różnicowania zakresu kompensacji szkód ze względu na okoliczności ich doznania wskazują po części postanowienia Konstytucji. Ustawa zasadnicza w stosunku do weteranów walk o niepodległość deklaruje zapewnienie im specjalnej opieki (art. 19). Nie określa przy tym pojęcia weteranów walk o niepodległość oraz dziedzin życia społecznego, składających się na obowiązek opieki nad weteranami, ani szczegółowych rozwiązań, które miałyby służyć jego urzeczywistnieniu.

Przykładowo ustawa o zaopatrzeniu inwalidów wojennych i wojskowych oraz ich rodzin przyznaje inwalidom wojennym, inwalidom wojskowym i członkom rodzin pozostałym po żołnierzach poległych, zmarłych lub zaginionych w czasie służby wojskowej oraz po inwalidach wojennych i wojskowych świadczenia pieniężne obejmujące rentę inwalidzką wraz z dodatkiem pieniężnym, rentę rodzinną, dodatki do rent oraz zasiłek pogrzebowy, a także świadczenia w naturze obejmujące świadczenia lecznicze i położnicze, protezowanie, przysposobienie zawodowe i pobyt $\mathrm{w}$ domu rencistów oraz liczne uprawnienia i przywileje, to jest: prawo inwalidy wymagającego leczenia sanatoryjnego do skierowania na pobyt w sanatorium co najmniej raz na trzy lata niezależnie od urlopu wypoczynkowego 
przysługującego mu z tytułu zatrudnienia, możliwość poddania go specjalnemu leczeniu, przeszkoleniu oraz usprawnieniu w ośrodkach rehabilitacji w celu całkowitego lub częściowego przywrócenia zdolności do pracy albo zapobieżenia pogorszeniu stanu zdrowia, a także pierwszeństwo w umieszczaniu w domu kombatanta lub domu pomocy społecznej, prawo inwalidy do zapewnienia mu przez starostę pracy odpowiadającej jego sprawności fizycznej i kwalifikacjom zawodowym, uprawnienie do ulgowych przejazdów środkami publicznego transportu zbiorowego (komunikacji miejskiej i krajowej), zwolnienie z opłat abonamentowych za używanie odbiorników radiowych i telewizyjnych, częściową refundację składki opłaconej tytułem obowiązkowego ubezpieczenia odpowiedzialności cywilnej posiadaczy pojazdów mechanicznych lub dobrowolnego ubezpieczenia casco pojazdów lądowych. Osobom pobierającym rentę rodzinną ustawa przyznaje zaś prawo do bezpłatnych świadczeń leczniczych, przedmiotów ortopedycznych, protez, środków pomocniczych, leków i środków opatrunkowych oraz świadczeń położniczych, a także prawo pierwszeństwa umieszczenia ich dzieci w żłobkach, domach dziecka, przedszkolach. Dodatkowo dzieciom pobierającym rentę rodzinną po zmarłym żołnierzu lub inwalidzie wojskowym ustawa przyznaje pomoc pieniężną na kontynuowanie nauki, nie dłużej jednak niż do ukończenia 25. roku życia.

Zdecydowanie bardziej rozbudowany katalog świadczeń przewiduje ustawa kombatancka. Przyznaje ona kombatantom, a także osobom, które podlegały represjom wojennym i okresu powojennego, zaliczonym do jednej z grup inwalidów wskutek inwalidztwa powstałego w związku z działalnością kombatancką lub represjami, jak również członkom ich rodzin świadczenia pieniężne i uprawnienia przysługujące inwalidom wojennym i wojskowym oraz członkom ich rodzin. Poza tym w stosunku do wymienionych osób niemających prawa do emerytury lub renty na podstawie przepisów o zaopatrzeniu inwalidów wojennych i wojskowych oraz ich rodzin oraz na podstawie innych przepisów i nieposiadających niezbędnych środków utrzymania ustawa przewiduje możliwość przyznania, w drodze wyjątku, prawa do emerytury po osiągnięciu wieku 55 lat w przypadku kobiet i 60 lat w przypadku mężczyzn oraz prawa do renty z tytułu niezdolności do pracy, jeżeli zostali uznani za niezdolnych do pracy, a na rzecz członków ich rodzin, spełniających warunki wymagane do uzyskania renty rodzinnej, renty rodzinnej, odpowiednio, w wysokości najniższej emerytury, renty z tytułu niezdolności do pracy lub renty rodzinnej określonych w przepisach ustawy emerytalnej (świadczenia fakultatywne) $)^{30}$. Do wyjątkowych emerytur i rent z tytułu niezdolności do pracy należy dodatek pielęgnacyjny, a do renty rodzinnej — dodatek dla sierot zupełnych. W obu przypadkach na zasadach i w wysokości określonej w przepisach ustawy emerytalnej. Po śmierci osoby uprawnionej do wskazanych świadczeń wyjątkowych przysługuje zasiłek pogrzebowy. Kombatantom i innym osobom

30 Por. wyrok WSA w Warszawie z 6 lipca 2016 roku, II SA/Wa437/16, LEX nr 2090001. 
uprawnionym pobierającym emeryturę lub rentę (w tym w drodze wyjątku) albo uposażenie w stanie spoczynku bądź uposażenie rodzinne ustawa przyznaje dodatkowo dodatek kombatancki, dodatek kompensacyjny w wysokości $15 \%$ dodatku kombatanckiego oraz ryczałt energetyczny (uprawnienie do dodatku kompensacyjnego i ryczałtu energetycznego przysługuje również wdowom lub wdowcom - emerytom i rencistom oraz osobom pobierającym uposażenie $\mathrm{w}$ stanie spoczynku lub uposażenie rodzinne). W świetle przepisów tej ustawy kombatanci i inne osoby uprawnione niemające prawa do żadnych świadczeń rentowych lub emerytalnych ani prawa do uposażenia w stanie spoczynku albo uposażenia rodzinnego, nieosiągające dochodów z tytułu pracy, pozarolniczej działalności gospodarczej podlegającej ubezpieczeniu społecznemu lub z tytułu rolniczej działalności gospodarczej podlegającej obowiązkowemu ubezpieczeniu rolników i które osiągnęly wiek 55 lat w przypadku kobiet i 60 lat w przypadku mężczyzn mają prawo do świadczenia w wysokości dodatku kombatanckiego. Dodatkowo kombatantom i innym osobom uprawnionym oraz pozostałym po nich wdowom lub wdowcom (emerytom, rencistom, inwalidom, osobom pobierającym uposażenie w stanie spoczynku lub uposażenie rodzinne) znajdującym się w trudnej sytuacji materialnej oraz w związku z zaistnieniem zdarzeń losowych ustawa stwarza możliwość przyznana doraźnej lub okresowej pomocy pieniężnej. Pomoc ta może być przyznana również na częściowe pokrycie kosztów zakupu wózka inwalidzkiego, sprzętu rehabilitacyjnego, przedmiotów ortopedycznych, środków pomocniczych, dostosowanie pomieszczeń mieszkalnych do rodzaju inwalidztwa oraz opłacanie pomocy pielęgnacyjnej. Poza wskazanymi świadczeniami pieniężnymi kombatanci korzystają z: prawa uwzględniania przy ustalaniu prawa do świadczeń emerytalno-rentowych okresów działalności kombatanckiej (działalności równorzędnej) oraz okresów represji w podwójnym wymiarze, pierwszeństwa do środowiskowej opieki socjalnej w miejscu zamieszkania, w uzyskaniu miejsc w domach pomocy społecznej, w szczególności w domach przeznaczonych dla kombatantów, a także z prawa do ulg taryfowych przy przejazdach środkami publicznego transportu zbiorowego. Kombatantom i innym osobom uprawnionym urodzonym przed 1 stycznia 1949 roku przysługuje również prawo do wcześniejszego przejścia na emeryturę, jeżeli mają okres zatrudnienia wymagany do uzyskania emerytury.

W przeciwieństwie do szkód doznanych przez inwalidów wojennych, wojskowych, kombatantów i osoby represjonowane szkody będące następstwem czynu zabronionego kompensowane są wyłącznie w formie jednego świadczenia — państwowej kompensaty. W myśl przepisów ustawy o kompensacie kompensata jest świadczeniem pieniężnym adresowanym do 1) ofiary przestępstwa, to jest osoby fizycznej, która na skutek czynu zabronionego poniosła śmierć albo doznała naruszenia czynności narządu ciała lub rozstroju zdrowia trwającego dłużej niż 7 dni (tak zwany ciężki lub średni uszczerbek na zdrowiu) oraz 2) osoby najbliższej ofiary, która na skutek czynu zabronionego poniosła śmierć (to jest małżonka lub osoby pozostającej z ofiarą we wspólnym pożyciu, wstępnego, zstępnego, osoby 
pozostającej w stosunku przysposobienia). Kompensata jest przy tym świadczeniem o podwójnie ograniczonym zakresie przedmiotowym. Po pierwsze, może być przyznana w kwocie pokrywającej wyłącznie utracone zarobki lub inne środki utrzymania, koszty związane z leczeniem i rehabilitacją oraz koszty pogrzebu, będące skutkiem popełnienia przestępstwa. Po drugie, ustawa wskazuje maksymalną wysokość kompensaty, która nie może przekroczyć 25 tys. zł, a gdy ofiara poniosła śmierć - 60 tys. zł. Dodatkowe ograniczenia przedmiotowe kompensaty wynikają z jej subsydiarnego charakteru w stosunku do odpowiedzialności sprawcy i możliwości zaspokojenia potrzeb wywołanych przestępstwem z innych źródeł. Kompensatę przyznaje się bowiem jedynie wówczas i w takiej wysokości, w jakiej osoba uprawniona nie może uzyskać pokrycia utraconych zarobków, innych środków utrzymania lub kosztów związanych z leczeniem, rehabilitacją oraz pogrzebem od sprawcy (sprawców) przestępstwa, z tytułu ubezpieczenia, ze środków pomocy społecznej albo z innego źródła lub tytułu, niezależnie od tego, czy sprawca lub sprawcy czynu zabronionego zostali ustaleni.

Rozważając zagadnienie zakresu ochrony ryzyka szkody doznanej w szczególnych okolicznościach, wypada dodać, że w większości aktów prawnych uchwalonych do końca lat dziewięćdziesiątych XX wieku podstawową formą ochrony tego ryzyka są świadczenia rentowe, to jest renta $\mathrm{z}$ tytułu niezdolności do pracy i renta rodzinna jako świadczenie pochodne wobec uprawnienia do renty z tytułu niezdolności do pracy osoby bezpośrednio poszkodowanej, ustalane z wykorzystaniem rozwiązań z zakresu ubezpieczenia rentowego, zwłaszcza pojęcia niezdolności do pracy. W przypadku zaś później uchwalonych aktów, z wyjątkiem ustawy o zaopatrzeniu z tytułu wypadków i chorób zawodowych w szczególnych okolicznościach, prym wiodą świadczenia quasi-rentowe lub świadczenia nastawione na kompensację szkody biologicznej - uszczerbku na zdrowiu, w przypadku których niezdolność do pracy wpływa tylko na ich wysokość.

Uznając za zasadne zróżnicowanie zakresu świadczeń w zależności od kontekstu doznania szkody, wpływającego na ocenę wartości społecznego życia jednostki i w konsekwencji podstawy odpowiedzialności zbiorowej za szkody na osobie, należy się zastanowić, jakie przejawy szkody doznanej w szczególnych okolicznościach powinny być docelowo objęte ochroną w ramach świadczeń chroniących analizowane ryzyko. Warto rozważyć, czy ryzyko szkody doznanej w szczególnych okolicznościach powinno być chronione tak jak aktualnie w systemach świadczeniowych, póki co wiodących jeszcze prym w praktyce (zaopatrzeniu ofiar wojny i represji powojennych), przede wszystkim w zakresie, w jakim szkoda wpływa niekorzystanie na zdolność zarobkową jednostki, a więc $\mathrm{w}$ formie świadczeń rentowych kompensujących szkodę ujawniającą się w niezdolności do pracy, a w przypadku osób pośrednio poszkodowanych w formie świadczenia pochodnego - renty rodzinnej i dodatków do niej.

Mając na względzie, że zabezpieczenie społeczne w zakresie niezdolności do pracy realizowane jest przede wszystkim przy użyciu konstrukcji ubezpieczenia 
społecznego, i biorąc pod uwagę powszechny charakter ubezpieczenia społecznego oraz uznając za zasadną potrzebę koordynacji świadczeń zabezpieczenia społecznego, można przyjąć, że ryzyko szkody powstałej w szczególnych okolicznościach powinno być chronione przez świadczenia kompensujące szkody na osobie niedotyczące zdolności do pracy. Szkodę na osobie w zakresie zdolności do pracy świadczenia te powinny kompensować tylko posiłkowo. W konsekwencji podstawowym świadczeniem dla wszystkich bezpośrednio poszkodowanych niezależnie od wieku mogłaby być renta z tytułu stałego lub długotrwałego uszczerbku na zdrowiu o charakterze fizycznym lub psychicznym. Świadczenie to mogłoby również kompensować szkody pośrednie (szkody szokowe), to jest uszczerbki na zdrowiu, zwłaszcza o charakterze psychicznym, doznane przez świadków zdarzenia szkodzącego (na przykład przestępstwa) lub bliskich bezpośrednio poszkodowanego po jego śmierci lub wobec doznanych przez niego obrażeń ${ }^{31}$. Walorem tak ukształtowanego systemu ochrony ryzyka szkody powstałej w szczególnych okolicznościach byłoby to, że nie redukowałby on ról życiowych poszkodowanego do roli w życiu zawodowym mierzonej tym, w jakim stopniu poszkodowany może w nim jeszcze uczestniczyć, podkreślając negatywny wpływ uszczerbku na wszystkie obszary życia poszkodowanego ${ }^{32}$. To, że środki na jego realizację wypracowywane byłyby przez całe społeczeństwo, zwłaszcza osoby faktycznie zarobkujące ${ }^{33}$, przemawiałoby za potrzebą uczynienia w jego konstrukcji prawnie istotnym tylko uszczerbku przekraczającego pewien próg minimalny. Konstrukcja postulowanego świadczenia opierałaby się na założeniu, że uszczerbek na zdrowiu powoduje wzrost kosztów utrzymania w porównaniu do stanu sprzed doznania szkody oraz że trwałość lub długotrwałość naruszenia sprawności organizmu uzasadnia potrzebę regularnego dostarczania środków ze względu na utrzymywanie się stanu zwiększenia potrzeb. W modelu mającym za podstawę wskazaną rentę negatywne skutki szkody doznanej w szczególnych okolicznościach w zakresie

${ }^{31}$ Kompensacje szkód szokowych w różnym zakresie i na różnych zasadach przewidują systemy odszkodowania dla ofiar przestępstw niektórych państw członkowskich UE, na przykład ustawodawstwo niemieckie, austriackie, francuskie i holenderskie. Szerzej U. Becker, Y. Körtek, Opferentschädigungsrecht in Europa - Ausgestaltung, Prinzipien und Zielsetzung im Vergleich, „Zeitschrift für ausländisches und internationales Arbeits und Sozialrecht” 2010/2011, nr 1-2, s. 188-189. Kompensację szkód szokowych na rzecz osób pośrednio poszkodowanych, na przykład świadków przestępstwa, osób, które znalazły ofiarę przestępstwa, bliskich ofiary, przewiduje również roboczy projekt XIII tomu kodeksu socjalnego. Zob. S. Nielsson, Die Zukunft des Sozialen Entschädigungsrechts?, „Die Sozialgerichtsbarkeit. Zeitschrift für das aktuelle Sozialrecht” 2017, s. 381-382.

32 W tym kierunku w 2007 roku zmieniono niemieckie ustawodawstwo, zastępując ustalane procentowo pojęcie obniżenia zdolności zarobkowej (niem. MdE — Minderung der Erwerbsfähigkeit) stopniem następstw poniesionego uszczerbku (niem. GdS — Grad der Schädigungsfolgen). Szerzej D.H. Dau, Der lange Weg vom RVG zum neuen sozialen Entschädigungsrecht, „SozialRecht aktuell. Sonderheft" 2017, s. 5.

33 Por. J. Jończyk, Sposób i miara zabezpieczenia społecznego, „Państwo i Prawo” 2011, nr 10, s. 5-11, 14-15. 
zdolności do pracy zarobkowej, w tym zmniejszenia dochodów, kompensowane byłyby na zasadzie wyjątku w formie odpowiednich dodatków wyrównawczych. Leżące u podstaw tego modelu założenie o komplementarnym charakterze świadczeń odszkodowania socjalnego względem systemów nastawionych na ochronę niezdolności do pracy, w polskim systemie zwłaszcza ubezpieczenia społecznego, uzasadniałoby przyznanie ich w sytuacjach, w których doznana przez bezpośrednio poszkodowanych szkoda na osobie w zakresie zdolności do pracy nie byłaby objęta ochroną w ramach tych systemów. W konsekwencji do wskazanej renty podstawowej przysługiwałyby dodatki wyrównawcze dla osób:

— aktywnych zarobkowo przed doznaniem szkody w szczególnych okolicznościach, uznanych w następstwie jej doznania za niezdolnych do pracy dla celów rentowych, ale nieuprawnionych do renty z tytułu niezdolności do pracy;

- aktywnych zarobkowo przed doznaniem szkody w szczególnych okolicznościach, nieuznanych w następstwie jej doznania za niezdolnych do pracy dla celów rentowych, legitymujących się wysokim procentowym stopniem uszczerbku na zdrowiu;

— nieaktywnych zarobkowo przed doznaniem szkody, legitymujących się wysokim stopniem uszczerbku na zdrowiu, które doznały szkody na osobie w szczególnych okolicznościach po osiągnięciu wieku produkcyjnego, ale przed osiągnięciem wieku podważającego społeczne przyzwolenie na nieaktywność zarobkową.

Swoisty charakter renty odszkodowawczej umożliwiałby łączenie jej pobierania ze świadczeniami długoterminowymi, w tym zwłaszcza z tytułu niezdolności do pracy. Komplementarność dodatków wyrównawczych wobec świadczeń długoterminowych uwarunkowanych niezdolnością do pracy eliminowałaby potrzebę uregulowania kwestii zbiegu prawa do tych świadczeń.

Za przyjętym modelem ochrony przemawiają również wątpliwości co do przydatności stosowania na potrzeby obecnych świadczeń rentowych definicji niezdolności do pracy stworzonej do celów rentowych, odnoszącej się do ochrony socjalnej okresu aktywności zarobkowej (zawodowej) czy też inaczej ochrony osób, które podjęły aktywność zarobkową i z tego względu akcentującej mocno elementy zawodowe. Tymczasem ryzyko szkody powstałej w szczególnych okolicznościach nie wiąże się z istnieniem stosunku zatrudnienia czy też szerzej — aktywnością zarobkową jednostki. Poza tym na doznanie szkody na osobie w szczególnych okolicznościach narażone są osoby niemające jeszcze w ogóle zdolności do pracy z racji wieku oraz osoby ją mające, ale nieuczestniczące już lub jeszcze w życiu zawodowym. Generalnie daje to możliwość innego ujmowania niezdolności do pracy niż sposób ujęcia wynikający z definicji przyjętej na potrzeby rentowe i stosowanej poprzez odesłanie do świadczeń rentowych chroniących aktualnie ryzyko szkody powstałej w szczególnych okolicznościach.

Poza tym ochrona ryzyka szkód powstałych w szczególnych okolicznościach powinna uwzględniać świadczenia uznane w opracowaniu za przejaw socjalnego 
zadośćuczynienia za szkody na osobie pozwalające poszkodowanemu na uczestnictwo w społeczeństwie. Ryzyko szkód powstałych w szczególnych okolicznościach mogłyby chronić również świadczenia kompensujące szkody w mieniu, które można traktować na równi ze szkodami na osobie, to jest szkody dotyczące przedmiotów przejmujących lub wspierających określone funkcje organizmu (na przykład okularów, soczewek kontaktowych, protez, kul, wózków inwalidzkich).

\section{UWAGI KOŃCOWE}

Zagadnienie ryzyka szkody powstałej w szczególnych okolicznościach (lub jego koncepcyjnego odpowiednika) i jego prawnej ochrony wymaga podjęcia szerszej refleksji naukowej. Jest ona niezbędna do oparcia ochrony tego ryzyka na spójnej uporządkowanej koncepcji, tym bardziej że ryzyko to nie ma aktualnie charakteru przejściowego. Nie odnosi się bowiem wyłącznie do okoliczności historycznych i systemów świadczeniowych typu interwencyjnego, ale również do świadczeń ukształtowanych prospektywnie, to jest świadczeń dotyczących okoliczności, które rodzą aktualnie niebezpieczeństwo doznania szkody.

Za potrzebą podjęcia głębszej refleksji naukowej na temat ryzyka szkód powstałych w szczególnych okolicznościach przemawia możliwość zwiększenia się zakresu przedmiotowego świadczeń służących jego ochronie. Wydarzenia ostatnich lat potwierdzają istnienie innych uwarunkowanych społecznie okoliczności, które mogą pozbawiać podstaw egzystencji wielu jednostek (rodzin) lub istotnie je naruszyć. Uwaga ta dotyczy zwłaszcza powodzi lub innych naturalnych zdarzeń klęskowych oraz ataków terrorystycznych ${ }^{34}$. Konstytucyjne prawo do ochrony życia i zdrowia, w tym obowiązek władz publicznych zwalczania chorób epidemiologicznych, którego wyrazem jest między innymi obowiązek szczepień ochronnych oraz udział państwa w organizacji publicznej służby krwi, może zaś uzasadniać wprowadzenie świadczeń z tytułu szkód będących następstwem wykonania obowiązku szczepień ochronnych oraz wynikłych z honorowego oddawania krwi - niemieszczących się w pojęciu zdarzenia medycznego, uzasadniającego przyznanie odszkodowania lub zadośćuczynienia w trybie przepisów ustawy z 6 listopada 2008 roku o prawach pacjenta i Rzeczniku Praw Pacjenta ${ }^{35}$.

Nie bez znaczenia na potrzeby podjęcia refleksji na ten temat pozostają również zmiany wprowadzone ostatnio przez ustawodawcę do regulacji prawnej ustaw normujących świadczenia kompensujące szkody związane z wydarzeniami

34 Szerzej zob. K. Stopka, op. cit., s. 286-292.

35 Zob. art. 67a-67p tej ustawy. Szkody związane z wykonaniem obowiązkowych szczepień ochronnych oraz związane z pobraniem krwi (jej składników) lub zabiegami towarzyszącymi podlegają wynagrodzeniu według norm prawa cywilnego. W odniesieniu do szkód związanych z honorowym krwiodawstwem wskazują na to wprost przepisy ustawy 22 lipca 1997 roku o publicznej służbie krwi (Dz.U. z 2017 r. poz. 1371 ze zm., art. 12). 
historycznymi ustawą z dnia 15 marca 2019 roku o zmianie ustawy o kombatantach oraz niektórych osobach będących ofiarami represji wojennych i okresu powojennego oraz niektórych innych ustaw ${ }^{36}$. Nowelizacja złagodziła wyraźne wcześniej zróżnicowanie w uprawnieniach osób bezpośrednio poszkodowanych w związku z wydarzeniami historycznymi, w szczególności zagwarantowała wszystkim grupom bezpośrednio poszkodowanych znajdującym się w trudnej sytuacji materialnej, zdrowotnej oraz w związku z zaistnieniem zdarzeń losowych możliwość ubiegania się o jednorazową lub okresową pomoc pieniężną na analogicznych zasadach. Tym samym zasygnalizowała, że choć świadczenia chroniące ryzyko szkód powstałych w szczególnych okolicznościach nie dotyczą kwestii zasadniczych dla państwa i społeczeństwa z punktu widzenia ich prawidłowego funkcjonowania i rozwoju (na przykład kwestii demograficznej, problemu starzenia się społeczeństwa, edukacji, rozwoju rodziny demokratycznej z równym podziałem ról między małżonkami) oraz wykraczają poza podstawowe standardy zabezpieczenia społecznego, ustawodawca dostrzega potrzebę i przejawia wolę systemowego i spójnego ich ukształtowania.

\section{RISK OF DAMAGE CAUSED IN SPECIAL CIRCUMSTANCES}

\section{Summary}

Social risk is a theoretical and legal category used in particular to describe the function of social security benefits and to extract and characterize social security law (social law). In the text the author indicates the normative basis for extracting the risk of damage suffered in special circumstances and carries out its theoretical and legal analysis. The author explains terminological issues and indicates the structure of this risk, its content, and the current and postulated scope of its protection.

Keywords: social risk, social law, personal injury, social compensation, non-contributory benefits

\section{BIBLIOGRAFIA}

Babińska-Górecka R., Ryzyko socjalne, [w:] Wielka encyklopedia prawa, t. 12. Prawo socjalne, red. H. Szurgacz, Warszawa 2017.

Becker U., Körtek Y., Opferentschädigungsrecht in Europa - Ausgestaltung, Prinzipien und Zielsetzung im Vergleich, „Zeitschrift für ausländisches und internationales Arbeits und Sozialrecht" 2010/2011, nr 1-2.

Dau D.H., Der lange Weg vom RVG zum neuen sozialen Entschädigungsrecht, „SozialRecht aktuell. Sonderheft" 2017.

Jończyk J., Prawo zabezpieczenia społecznego, Kraków 2006.

Jończyk J., Sposób i miara zabezpieczenia społecznego, „Państwo i Prawo” 2011, nr 10.

Nielsson S., Die Zukunft des Sozialen Entschädigungsrechts?, „Die Sozialgerichtsbarkeit. Zeitschrift für das aktuelle Sozialrecht” 2017.

36 Dz.U. z 2019 r. poz. 752. Zob. również uzasadnienie do projektu ustawy 08.2671. 
Roszewska K., Ryzyko niezdolności do pracy, Warszawa 2018.

Stopka K., Świadczenia odszkodowania socjalnego w prawie polskim, Warszawa 2018.

Szumlicz T., Świadomość ryzyka społecznego jako podstawa wiedzy o systemie ubezpieczeń spotecznych, „Ubezpieczenia Społeczne. Teoria i praktyka” 2017, nr 1.

Szumlicz T., Ubezpieczenie budynków od skutków ryzyk katastroficznych — aspekt społeczny rozwiazań wariantywnych, [w:] Ubezpieczenie budynków od ryzyk katastroficznych. Aspekty prawno-ekonomiczne, red. E. Kowalewski, Torun 2013.

Szurgacz H., Europejska Konwencja o zabezpieczeniu społecznym, [w:] Europejskie prawo pracy i ubezpieczeń społecznych, red. L. Florek, Warszawa 1996.

Szurgacz H., Prawo socjalne w latach 1989-1999. Kilka uwag o kierunkach rozwoju, [w:] Prawo pracy a wyzwania XXI w. Księga Jubileuszowa Profesora Tadeusza Zielińskiego, red. M. Matey-Tyrowicz, L. Lawacki, B. Wagner, Warszawa 2002.

Ślebzak K., Prawo do zabezpieczenia społecznego w Konstytucji RP. Zagadnienia podstawowe, Warszawa 2015

Zacher H.F., Rozwój zabezpieczenia społecznego w Europie, [w:] Lad społeczny w Polsce i Niemczech na tle jednoczacej się Europy, red. M. von Bernd, T. Zieliński, Warszawa 1999. 